\title{
Analysis of Singapore Educational Tracking System
}

\author{
Yinghe Liu
}

Senior University of Washington, College of Education

lyh2000@uw.edu

\begin{abstract}
According to Programme for International Student Assessment (PISA) 2018 world ranking, Singapore is ranked 2nd in the world. This article aims to explore the educational system in Singapore focusing on its well-known tracking system, teaching idea of elitism, attitude for immigrants and educational downside. The result shows Singapore shares several advantages in education methods with other countries.
\end{abstract}

Keywords: educational system in Singapore, tracking system, PISA test

\section{INTRODUCTION}

The Programme for International Student Assessment (PISA) [4]is a worldwide study by the Organization for Economic Co-operation and
Development (OECD) in member and non-member nations intended to evaluate educational systems by measuring 15-year-old school pupils' scholastic performance on mathematics, science, and reading(Wikipedia contributors, 2021). According to the result, Singapore is ranked at the 2 nd place in the world.

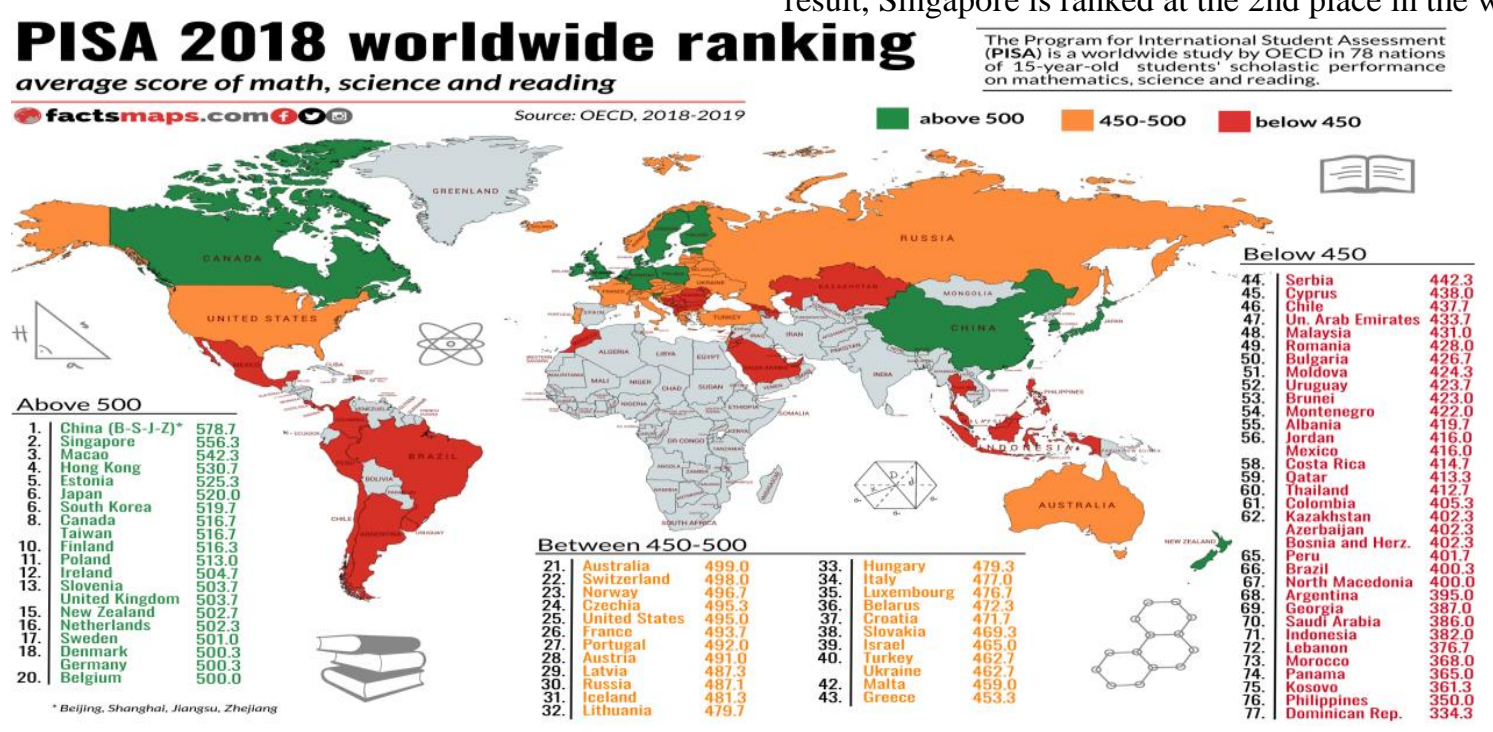

Figure 1.PISA 2018 worldwide ranking

When I was in seventh grade in China, I got the opportunity to participate in a 7-day exchange program in Singapore. Singapore was the first foreign country that I visited and I always heard good words about it from my parents such as the beautiful Merlion Park and the neat road. During the exchange week, we not only got to see the beautiful scenery but also got to visit the best University in this country--National University of
Singapore(NUS). According to the QS World University, NUS is ranked as the best University in Asia. Throughout the pedagogy in Asian countries, Singapore educational system definitely owns things worthy further exploration. In this article, I would like to explore the education system in Singapore focusing on its tracking system and the teaching idea. 


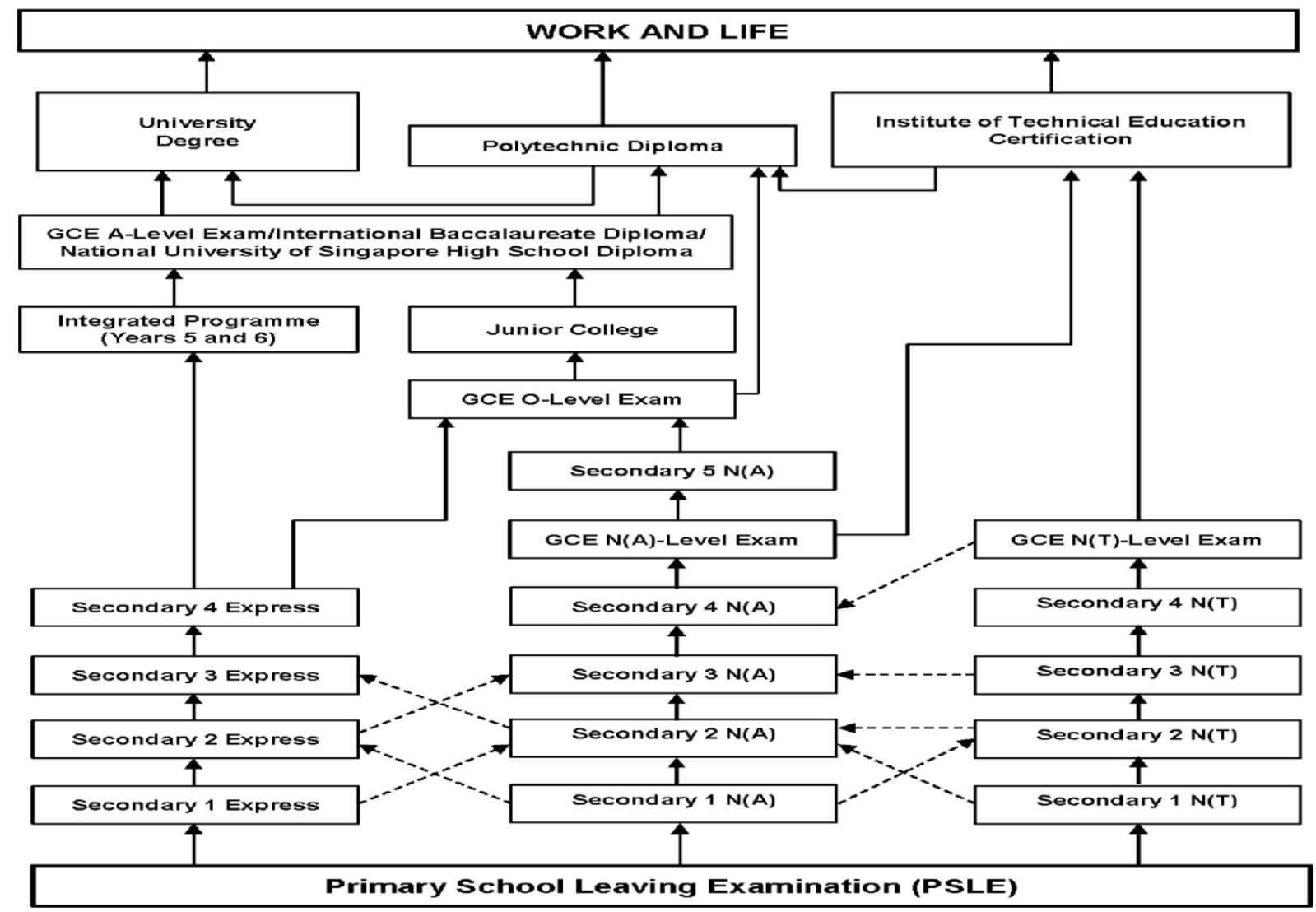

Figure 2. tracking system

\section{EDUCATIONAL SYSTEM}

\section{1 model emphasizing elitism}

First, we need to know that the society of Singapore emphasizes elitism especially in their educational system. [3]As the CEO of Wise says, "The elitist tendency in Singapore's education system is tempered by the fact that quality education is available for all levels of academic aptitude"(Stavros 2015). Different from the United States who believes every student should receive equal education resources, Singapore believes that each Singaporean needs to be trained to his full potential and students should receive the kind of education that

best suits them instead. The concept of meritocracy has taught the students that everyone has the opportunity to get in the top pyramids where the elites belong to as long as they study and work hard. However, the emphasize of elitism has received certain critic at the same time as educators point out, "As a result, our youths grow up believing that if they succeed, it is solely due to their hard work. [6]By the same logic, they also believe that if others fail, it is not because of structural factors but solely because of one's laziness or incompetence"(2017).

\section{2 tracking system}

Kids in Singapore had to receive the Primary School Leaving Examination(PSLE) in sixth grade, which determines which secondary school they are going to. Tracking children after primary school is one of the promising practices of the Singapore education system. For example, fast-learners complete their secondary courses in four years while the ones who learn relatively slower may complete the same work in five years. There is also another option for students who are not good at academic work: electing to study more vocational subjects. Again, Singapore believes that students should receive the education that best suits them and making students receive education at the same level as difficult results in a high dropout rate. For years, the tracking system and the placement test had managed to cut down the dropout rate tremendously. [2]According to the data, The dropout rate in Singapore is now at $1.6 \%$, and has been decreasing considerably from $5.3 \%$ in 1997 and $3.6 \%$ in 2002 (2018). 


\section{3 welcome for immigrants}

Another promising practice of Singapore's education system is this country's welcome for immigrant elites. While a lot of people in the United States blame the unsatisfactory ranking of their country on immigrant children, Singapore proved to the world the values brought by immigrant students. Having a $40 \%$ percent immigrant population, Singapore has always been very open to immigrants and believes in the values they would bring to their country. [1]In 2017, the expert analyzed data from the 2012 Programme for International Student Assessment (PISA) and claimed "On average, comparing students of the same grade level, immigrant students outperform native students by $0.40,0.35$ and 0.31 standardized point respectively in maths, science and reading" (Cheng 2017). The data has proved that the immigrant children help enhance the overall competitiveness and student performance in Singapore. The friendly attitude and high welfare towards immigrants have brought enormous value to this beautiful island.

\section{DOWNSIDE TO SINGAPORE'S WORLD- CLASS EDUCATION SYSTEM}

While standardized tests are a crucial method for examining progress in a country's education system, they can lead to competition and stress to some extend as the same time. Having the PSLE early at sixth grade, Singaporean kids are forced to learn to digest the pressure at a very early age. The PSLE test receives much attention from teachers, parents and students, which is considered the first test that would affect a student's future. Not only students need to suffer from the extreme stress and countless tests, parents in Singapore also need to face the financial stress from paying the tuition and the expensive tutor in order to send their kids to the best school they could enter.

\section{COMPARISON WITH EDUCATIONAL SYSTEMS IN OTHER COUNTRIES}

Making a general observation of the worldwide ranking, it is interesting to perceive certain similarities between Singaporean education system and other countries. Similar to South Korea, Singapore does not have an advantage in geography as well. With the size of half city of Los Angeles and not so much natural resources, gaining better education resources becomes the key to future career development. The severe "Hagwon"(cram school) culture in South Korea also exists in Singapore, causing the imbalance of learning energies inside and outside schools .

It is also worth noted that even though Singapore and China are ranked No.1 and No.2 on PISA, these two countries have a totally different level on their WHR (World Happiness Ranking). With all that pressure from standardized tests, Singapore still ranks 32nd on the World Happiness Report(a much higher ranking than China), and that causes my curiosity. What makes Singapore have a much higher WHR score but similar PISA score with China at the same time? After some research, I found the answer: Singaporean education system offers students a more autonomy learning environment. Students have certain freedom on choosing their interested subjects.

Similar to Finland, Singapore also has highly selective and rigorous training for teachers. [5]According to the article Imagining School Autonomy in HighPerforming Education Systems: East Asia as a Source of Policy Referencing in England, "In Singapore, the vast majority of teachers are 'appointed teachers'; they are degree holders, centrally selected and trained at the National Institute of Education, appointed as civil servants and assigned to schools by the SMOE based on central needs as well as their preferences" (Yun 2015). Therefore, we could see that the high quality of teachers in this country is also something made the high quality of learning.

\section{CONCLUSION}

Admittedly, there are many advantages about the educational system in Singapore that are worth learning by other countries in the world. Hopefully, this article shows readers the power guided by the certain educational methods tapping the potential of students in Singapore and causes more reflections on modern pedagogy. However,the stress issue is not supposed to be neglected as well. In the future study, how to maximize every student's potential and minimize the following stress is the topic educators should continuing paying attention and working on. 


\section{DISCLOSURE STATEMENT}

The author declares no conflict of interest.

\section{REFERENCES}

[1] Kelvin Seah Kah Cheng. "Immigrants Outdo Native Students in Studies, Opinion News \& Top." The Straits Times, 14 June 2017, www.straitstimes.com/opinion/immigrants-outdonative-students-in-studies.

[2] Ministry of Education. "Helping Students Who Are At-Risk of Dropping-Out Stay in School." Press Release, 2008, www.nas.gov.sg/archivesonline/data/pdfdoc/20080 304993.pdf.

[3] Stavros N. Yiannouka. "The secret of Singapore's success in education." The Straits Times, 19 Jan. 2016,www.straitstimes.com/opinion/the-secret-ofsingapores-success-in-education.

[4] Wikipedia contributors. (2021, August 22). Programme for International Student Assessment. Wikipedia.

https://en.wikipedia.org/wiki/Programme_for_Inter national_Student_Assessment

[5] You, Yun, and Paul Morris. "Imagining School Autonomy in High-Performing Education Systems: East Asia as a Source of Policy Referencing in England." Compare: A Journal of Comparative and International Education, vol. 46, no. 6, 2015, pp. 882-905.

Crossref, doi:10.1080/03057925.2015.1080115.

[6] Why elitism in Singapore exists \&amp; how to change it. Jeraldine Phneah. (2017, December 20). Retrieved September 22, 2021, from https://www.jeraldinephneah.com/elitism-insingapore/. 